\title{
Evaluation Analysis of SAP (Responsibility Application System" Quality based on ISO 9126
}

\section{(Case Study: Indonesian Ministry of Communication and Information)}

\author{
Fahmi Riskian \\ *Faculty of Economics and Business \\ DOI: 10.29322/IJSRP.11.08.2021.p11642 \\ http://dx.doi.org/10.29322/IJSRP.11.08.2021.p11642
}

\begin{abstract}
Alongside with the development of science and technology, the use of information and communication technology (ICT) within an organizational environment has become a necessity in achieving institutions' efficiency and effectiveness. Added with the major impacts on the globalization, Indonesian government has embedded digital transformation as the country's prioritized agenda - known from the new policies and programs taken by the government. As part of the central government that helps the President, Indonesian Ministry of Communication and Information or known as "Kominfo" occupies a strategic and practical position for the implementation of digital transformation in Indonesia. However, in the real life, Kominfo's staffs spend too much time working on administrative work, instead of the substantial ones. The long and rigid bureaucracy, added with conventional administrative practices are considered as the two big factors of the hindered system. Understanding the issue, since 2017, Directorate General of Aptika (Ditjen Aptika) - as part of the Kominfo itself has been implemented a new digitized administration system called "SAP", in hoping to address the challenges. As the result, the bureaucratic process of Assignment Letter (AL) is successfully reduced by 90 percent, from the whole process that usually took up to five days were reduced to only three to four hours. This research is aimed to evaluate SAP system that belongs to Ditjen Aptika by using the ISO 9126 standard. Furthermore, this research use several relevant theories and concepts, namely workload analysis, operating system, quality management, quality and application of software improvement processes, done with qualitative approach and observation, completed with in-depth interview as the data collection techniques.
\end{abstract}

Index Terms- Digital Transformation, Ditjen Aptika, ISO 9126, Kominfo, SAP

\footnotetext{
${ }^{\text {i }}$ Royyana, A. Strategi Transformasi Digital Pada PT. Kimia Farma (Persero) Tbk. Journal of Information Systems for Public Health, III(3), 2018, pp. 15-32
}

\section{INTRODUCTION}

$\mathrm{T}$ he existence of communication and information technology (ICT) that continues to evolve to this day has shifted and changed how human interacts globally almost without exception. The shift happens due to the integration of the technology itself in humans' everyday lives massively, breaking boundaries across countries, space, and time, which then furthermore we call as "digitalization". Digitalization is the use of digital technology such as remote sensors, intelligent machine, big data, and real-time communication to improve processes, product and service quality, and optimize resource allocation for businesses ${ }^{1}$ The idea that digitalization has a relevancy with globalization has led us to the world we know today - borderless, with no boundaries and everything happens very fast and instant, leading to a complete digital transformation.

Considering the practical dynamics of the competitive business and the rapid technology penetration, more businesses in Indonesia has become more open to the changes, including the government institutions. The Indonesian Ministry of Communication and Information Technology (Kominfo) holds a strategic position during the digital transformation era and has seven working units. The Directorate General of Informatics Applications (Ditjen Aptika). According to the Regulation of the Minister of Communication and Information Technology, Ditjen Aptika has seven operational functions; (1) Policy maker for egovernment, e-business, and information security management, improvement of information technology and application infrastructure and informatics; (2) Policy enforcement for eGovernment, e-Business, and information security management, improvement of information technology and application infrastructure and informatics; (3) Preparations of norms, standards, and criteria for e-Government management, (4) Providing technical guidance and supervision on e-Government implementation; (5) Evaluating and reporting on e-Government 
management, e-Business, and information security management, improvement of information technology and application infrastructure and informatics; (6) Administration enforcement within the institution itself; (7) Added functions executor assigned by the Minister ${ }^{2}$

In 2016, Indonesian President, Joko Widodo made a statement on a research result that highlighted a poor HR management amongst government institutions, shown by up to 60-70 percent of the state staffs spend their time too much working on administration work for accountability letters $(S P J)$ instead of focusing on the substantive ones. Additionally, the President urged for a whole systematical change to address the issue, which one of them is to escalate digitalization amongst government institutions.

Responsible for leading the country's digital transformation major agenda, The Indonesian Ministry of Communication and Information Technology is considered as a pioneer amongst government institutions to implement the e-government into the bureaucracy system, proven by the 2016-2019 National eGovernment Roadmap assessed by the Ministry which is aimed to build clean, effective, democratic, and reliable governance through democratic and reliable governance through optimizing the use of ICT. Furthermore, the integration of technology into the system is expected to increase public satisfaction with the quality of government services and to improve the efficiency of processes within and between government agencies. In supporting the Ministry of Communication and Information Technology, Indonesian Ministry of Finance issued a designated regulation or known as PKM No. 302/PMK.01/2019 on the implementation of green office and paperless policy. The regulation was issued to drive all government institutions to adopt the digital transformation.

Understanding the main agenda, the Directorate General of Informatics Applications (Ditjen Aptika) initiated the use of integrated accountability software system known as "SAP" in 2018. Originally the idea was developed since 2017 and the main feature offered by SAP itself is to integrate the whole administrative processes, including assignment letter, invitations and official notes, finance, reports, document archives, attendance, calendar activity, employee data, and statistics. The purpose of SAP is to simplify the bureaucracy system by using an integrated system within the organization, thereby can increase the employees' productivity and efficiency. According to internal data, each month, Ditjen Aptika can receive more than 200 invitations both from internal and external government bodies and other parties such as private sectors or civil organization that are obligated to be transformed as assignment letter. The Guideline of Minister of Communication and Informatics No. 3/2019, Assignment Letter (AL) is an official document created by authorized officials to subordinate given assignment and is signed

\footnotetext{
${ }^{2}$ Ditjen Aptika. Profil Direktorat Jenderal Aplikasi Informatika. Ditjen Aptika Kominfo. Jakarta: author, 2015, pp. 7-18
}

${ }^{3}$ Fink, A. Conducting Research Literature Reviews: From the Internet to Paper, $4^{\text {th }}$ ed, 2014 by the authorized official, based on the scope of duties, authorities, and responsibilities. Throughout the development of the SAP itself, Ditjen Aptika integrate the SAP system with "Kendali" - the institution's specify application for the staffs which can be accessed through any device, including smartphones.

This study evaluates the use of SAP by using the ISO 9126 indicator standard, an internationally recognized standard specifically for software engineering by using the Directorate General of Aptika as the case study. The purpose of the study is to evaluate the usage of SAP application, to look for the effectiveness and implications of SAP on the workload analysis within the organization itself. Furthermore, the study will be used as a reference basis for the Indonesian Ministry of Communication and Information Technology's plan to expand the use of SAP within the whole institution body as well as to promote the system to other government bodies.

\section{IDENTIFY, RESEARCH AND COLLECT IDEA}

This study uses several relevant concepts, ideas, and thinking in supporting the study analysis by doing a literature review. Literature review surveys books, scholarly articles, and other sources relevant to a particular issue, area of research, or theory, and designed to provide an overview of sources explored while researching a particular topic and furthermore to demonstrate how the developed research fits within a larger field of study ${ }^{3}$ Furthermore, literature review may consist of simply summary of key sources, but in the social sciences, literature review usually has an organizational pattern, divided into specific conceptual categories.

\section{Workload Analysis}

Conceptually, digital transformation is seen as a phenomenon where organizational change happens and involves individuals, processes, strategies, and structures through the use of ICT models in improving businesses' performances or achieve company goals ${ }^{4}$ Furthermore, McKinsey's 2016 report stated that digital transformations require cultural and behavior practically that includes almost the whole process of business operations that emphasizes the main three points; calculated risk taking, increased collaboration, and customer centricity.

Referring deeper to McKinsey's 2016 report, the cultural and behavior transformation that supports the whole process of digital transformation itself has relevancies with institutions' human resource (HR) management. The definition of HR management as a whole process of employees, managers, and other labors management handling in order to support companies or

\footnotetext{
${ }^{4}$ Westerman, G., Calmejane, C., Bonnet, D., Ferraris, P., dan McAfee, A. Digital transformation: a road-map for billiondollar organizations. Cambridge: MIT Center for Digital Business and Capgemini Consulting, 2011
} 
organizations' goals ${ }^{5}$ Based on the basic concept of human approach by treating employees as human beings and not as machines, the Indonesian Law is strict in regulating HR management practically, which one of them through workload analysis. Moreover, workload analysis is a determination process that comprises employees' working hours needed to complete a job within a certain time. Conceptually, there are several benefits carried out by workload analysis, but two major benefits from effective workload analysis are more effective businesses' preparation and targeting plan in improving institutional performance and the ability of providing more humanist working environment for employees.

\section{Operation System}

The definition of operating system (OS) as a program that controls execution of application programs and act as an interface between applications and the computer hardware ${ }^{6}$ There are three purposes of the use of OS; (1) Convenience, where with the use of OS, a computer device is expected to be easier and more comfortable to use by users; (2) Efficiency, a condition where OS provides a sense of efficient to the users; (3) Ability to evolve, a condition where OS has the ability to evolve and develop without disrupting the service or the OS' operation itself. Furthermore, there are three main roles of OS as follows:

1) Operating System as a user/computer interface

In order to facilitate the operation of application program, OS is needed to bridge the multi-layered process given from the hardware and software applications used by end users.

2) Operating System as resource manager

Apart of being a user interface that helps end users to operate the device, OS also plays important role as a resource manager by controlling the data and sources on the device, including the basic functions of the device.

3) Ease of evolution of an operating system

Alongside with the ICT development and the behavior changes, OS undergoes changes and innovations from time to time with several objectives, namely the need for new services, such as control tools and bug fixing.

\section{Software Quality}

Conceptually, software is defined as a certain object that can be executed such as source code, object code or a complete program ${ }^{7}$ Pressman explains there are several characteristics of software; (1) Software can be developed and engineered, (2) Software does not expire throughout time, (3) Almost all software is still built traditionally, even though many industries have done componentbased assembly ${ }^{8}$ Moreover, in the context of the use of computer equipment, software quality is one of the most important components for its relevancy with how users can operate the device and receive the maximum benefits from it. Software quality is divided into two categories, internal that directly related with

\footnotetext{
${ }^{5}$ Abdullah, H. Peranan Manajemen Sumber Daya Manusia Dalam Organisasi. Jurnal Warta, 51, 2017, ISSN: 1829-7463

${ }^{6}$ Stallings, W. Operating Systems Internals and Designs

Principles $7^{\text {th }}$ ed, New Jersey: Pearson Education, 2012, pp. 48
}

the machine or device itself and external that refers to the users of the device.

Software quality can be assessed through certain measures and methods, as well as through software test. An international recognized standard called the International Organization of Standardization (ISO) collaborated with the International Electrotechnical Commission (IEC) in developing the ISO 9126 standard on software engineering for software quality. In addition, the ISO 9126 standard defines software product quality, models, characteristics quality, and related metrics used to evaluate and define the quality of a software product that are consisted of six characteristics as follows;

1) Functionality

The ability to provide functions according to the user's needs and satisfaction

2) Reliability

The ability to maintain a certain level of performance

3) Usability

The ability to understand, learn, use, and appeal to users

4) Efficiency

The ability to provide appropriate performance and relative to the amount of resources used at that time

5) Maintainability

The ability to be modified which includes correction, improvement or adaptation to change in the environment, requirements, and functional specifications

6) Portability

The ability to be transferred from one environment to another or to adapt when used in certain areas

\section{FINDINGS}

As an institution, a state has a set of supporting instruments that assist the central government in carrying out its state practice. Referring to Article 1 Para. 1 Indonesian Law 39/2008, State Ministry (Ministry) is defined as the government apparatus in charge of certain affairs and is led by a Minister. Consisting of seven working units to support its practice, the Ministry of Communication and Information Technology (Kominfo) is a government instrument stated in the 1945 Constitution that responsible for communication and information affairs.

As stated previously on the introduction, the Ministry of Communication and Information Technology has an important role which is to compile and lead the implementation of central government programs in the communication and information affairs in a directed and systematic manner as written in the Nawacita agenda Roadmap which consist of three points;

1) The 2016-2019 National e-Government Roadmap

\footnotetext{
${ }^{7}$ Ladjamudin, A. Analisis dan Desain Sistem Informasi, Yogyakarta: Graha Ilmu, 2006

${ }^{8}$ Pressman, R. S. Rekayasa Perangkat Lunak Pendekatan
Praktisi $1^{\text {st }}$ Ed, Yogyakarta: ANDI, 2015
} 
This roadmap is developed in order to build clean, effective, democratic, and reliable governance through the optimization use of ICT. Additionally, the scope referred to in this e-Government area is digital/electronic systems, governance, and high-level government through these sub-points:

a) Increasing public satisfaction with the quality of government services

b) Improving the efficiency and coordination within and between government agencies

2) The e-Commerce Roadmap

This roadmap is developed in support of local ecommerce industry ecosystem. By involving several other government bodies such as the Ministry of Trade, the Ministry of Cooperatives and SMEs, Indonesian Central Bank (BI), and the Investment Coordinating Board and Creative Economy Agency, the government formulated main principles to develop this industry for affirmative actions

3) The National Cyber-Security Strategy Specifically for this point, the Indonesian Ministry of Communication and Information Technology has compiled six priority areas, which consist of;

a) Building an information security and capacity

b) Managing information security risks

c) Building and implementing safeguards to reduce information security risks

d) Manage information security incidents

e) Improve information security performance

f) Increase law enforcement capacity in the field of electronic information and transactions.

\section{The SAP Application Process}

The main objective of SAP is to simplify the long and rigid bureaucracy within the Ditjen Aptika. Specifically for Assignment Letter process, the flow of SAP is divided into three stages. Firstly, an authorized staff create an Assignment Letter (AL) that contains the names of the assigned staffs, alongside with complete information; full name, employee number, class rank, and the purpose of the letter. Next, the prepared AL is uploaded to the SAP and Kendali integrated system and the document status will appear automatically in the system for approval which consist of three layers (verifier, validator, and signing).

The second step starts after the AL already receives approval or signature from an authorized senior, depending on the work unit and interest of the official document. Next, the authorized staff is required to create a collective official travel letter (SPD) for the next steps, consisting of more detailed official documents. The third and the last stage is a stage where all related official document are signed and approved, allowing the assigned staffs to complete their assignments.

Based on the observation process that has been conducted, the SAP system has successfully managed to cut the time duration for the whole three steps which previously took approximately up to five working days to only three to four hours at the maximum.

\section{SAP Evaluation Analysis}

Along with the acceleration of digital transformation experienced by Indonesia, influenced by the massive development of technology and information in the world, this certainly has an impact on the increasingly competitive business world. Therefore, in order to maintain the consistency of the quality of the products and services produced, it is necessary to have quality control or management. Conceptually, quality is a dynamic condition related to products, services, people, processes, and the environment that meet or exceed what is expected ${ }^{9}$ Meanwhile, according to ISO 8402 and the SNI institute quality is the overall characteristics and characteristics of a product or service whose ability to satisfy needs, both expressed and implied, where the term requirement here is defined as the specifications contained in the contract or criteria must be defined first.

Internationally, a standardized and globally recognized quality management system is known as the International Standard of Organization (ISO), a world standards body which was officially established in 1947 and was formed to increase international trade related to changes in goods and services. As a recognized international body, ISO collaborates with the International Electrotechnical Commission (IEC) in developing the ISO 9126 standard, which is an internationally recognized standard for software quality. More deeply, ISO 9126 contains standards for software quality factors consisting of six characteristics. Based on data retrieval, the researchers analyzed the quality of the SAP application by using each of the characteristics of the software quality factors contained in the ISO 9126 as follows,

\section{Functionality}

As one of the characteristics contained in ISO 9126, functionality points measure how a software has the ability to provide functions according to needs and satisfy users. If referring back to the basic purpose of developing the SAP application itself, the SAP application is designed and developed to support and facilitate the performance of the staffs in terms of work related to the bureaucracy that has been adapted to the characteristics and preferences of staffs within the organization itself. The researcher found that the SAP application already met these characteristics, as seen from the duration of the submission and approval of the Assignment Letter which was successfully cut by 90 percent, to only three to four hours.

\section{Reliability}

This characteristic includes the ability of the software to maintain a certain level of performance. Based on the researcher's analysis, the SAP application has met this point, as evidenced by SAP's ability to operate within the scope of Ditjen Aptika's environment. Operationally, the ICT coordinator of Ditjen Aptika always conducts thorough and routine monitoring of the system recovery process whenever a failure occurs. Based on internal data, the recovery process required by the system every time the

${ }^{9}$ Goetsch, D. L and Davis, B. S. Quality Management:

Introduction to Total Quality Management for Production, Processing, and Services, New Jersey: Prentice-Hall, 2002 
SAP system fails continues to increase by up to $60 \%$ due to the speed of time required

\section{Usability}

This point discusses how a software can be understood, learned, used, and attractive to users. Based on the results of surveys and in-depth interviews conducted by researchers, researchers found that the demographics of the staffs are quite diverse, consisting of generations X, Millennials, and even Z. If we analyze, then the ICT Division and SAP application developers has worked well in developing the SAP model in terms of the user interface (UI) which is easy to understand, making it easier for users to access the SAP system.

\section{Efficiency}

This point describes the software's ability to provide appropriate performance and relative to the amount of resources used at that time. As previously explained, through the SAP system, the institution has uniformed the format of the assignment letter submission template to the required activity reports for the staffs concerned.

\section{Portability}

Portability includes the ability of the software to be transferred from one environment to another or to adapt when used in a particular area. Based on the results of observations and analyzes carried out, the researchers found that the SAP system had met these characteristic points, one of the evidences was the availability of a location check-in feature that could be used by staffs on duty outside the city in real time which was also integrated with the system control.

\section{Maintainability}

This point includes the ability of the software to be modified which includes correction, improvement, or adaptation to changes in the environment, requirements, and functional specifications. Based on the results of observations and interviews conducted by researchers, until 2021, Ditjen Aptika has still focus on education in an effort to increase the number of users among the staffs and develop its own SAP application model.

Furthermore, another finding of the study is currently the SAP system is still at the development stage and it is necessary to conduct deeper system check on the whole system, especially considering the ultimate goal is for the system to be used by the whole Ministry. Therefore, there are several important steps that need to be taken as an evaluation; (1) To conduct periodically check and system back-end control, (2) To increase the system's multi-tasking capacity based on the expected of user number, (3) To develop a firmed standardized procedure on the SAP system control to be conducted on a regular basis, (4) To explore and develop the action-reaction and crisis procedures as a preventive measure for the sake of the system's security.

Referring back to the concept, workload analysis is an important tool that needs to be taken care of regularly by the management. The key of a healthy working environment is to create a safe place for the employees as humans and not as machines or robots. Based on the observation conducted, another key finding is there are some points that are related to workload analysis that have been addressed by the SAP. For more details on the comparison,

Table 1. Workload Comparative Analysis Table

Before the SAP
Tracking the administrative
submission process to find out
the length of time for approval
submitted by the staff. At first
before using the SAP
application which can take up
to 5 working days,

Different templates for submission of accountability administration from each SubDirectorate:

-Sub-directorate of Electronic System Governance and Digital Economy

- Sub-directorate of Personal Data Protection Governance - Sub-directorate of Government Electronic System Governance

- Sub-directorate of Electronic Certification Governance

The initial template used by each Sub-directorate does not yet refer to the script according to the Regulation of the Minister of Finance

There are differences in the submission of the requirements for accountability administration documents in each section of the Subdirectorate which has been mentioned in the previous point

The administrative process is done conventionally so it takes a long time

After the SAP

The entire administrative application process is standardized. successfully reduced by about $90 \%$ to only 3-4 hours.

A standardization of templates for all documents related to the submission of accountability administration which has referred to the draft of the Minister of Finance Regulation.

With this standardization, the synergy within the institution has also increased, including the implementation of the paperless policy from the Ministry of Finance because all submissions use a digital system.

$\begin{array}{ll}\text { The existence } & \text { of } \\ \text { standardization } & \text { of }\end{array}$
submission of requirements for accountability administration documents, making it easier for all staff, including the process of checking and auditing documents.

Integrated with the Kendali system, can be used with any device, the administrative process can be done very easily and simply, and does not need to take a long time like before.

The emergence of budget Through the SAP system, accountability redundancy redundancy or repetition of budget accountability can be avoided by up to $90 \%$, thanks to the transparency provided by the SAP system itself. This certainly increases the effectiveness of the use of the budget. 


\section{CONCLUSION}

Based on the research that has been done, the researcher can draw several conclusions. First, the results of this study indicate that the SAP application successfully fulfills almost all of the characteristic points of the ISO 9126 indicator consisting of functionality, reliability, usability, efficiency, portability, and maintenance. However, based on the results of further observations, it is necessary to increase the innovation of the SAP application itself, especially at the point of maintenance indicators. Second, the researcher found that the SAP application succeeded in increasing productivity and had a positive impact in the form of reducing the unbalanced workload. This is proved among other things, by cutting the duration of the submission and approval of the Assignment Letter by 90 percent, from initially taking up to five working days to only three to four hours.

\section{ACKNOWLEDGMENT}

The preferred spelling of the word "acknowledgment" in American English is without an "e" after the "g." Use the singular heading even if you have many acknowledgments.

\section{REFERENCES}

Royyana, A. Strategi Transformasi Digital Pada PT. Kimia Farma (Persero) Tbk. Journal of Information Systems for Public Health, III (3), 2018, pp. 15-32

Ditjen Aptika. Profil Direktorat Jenderal Aplikasi Informatika. Ditjen Aptika Kominfo. Jakarta: author, 2015, pp. 7-18

Fink, A. Conducting Research Literature Reviews: From the Internet to Paper, 4th ed, 2014
Westerman, G., Calmejane, C., Bonnet, D., Ferraris, P., dan McAfee, A. Digital transformation: a road-map for billion-dollar organizations. Cambridge: MIT Center for Digital Business and Capgemini Consulting, 2011

Abdullah, H. Peranan Manajemen Sumber Daya Manusia Dalam Organisasi. Jurnal Warta, 51, 2017, ISSN: 1829-7463

Stallings, W. Operating Systems Internals and Designs Principles 7th ed, New Jersey: Pearson Education, 2012, pp. 48

Ladjamudin, A. Analisis dan Desain Sistem Informasi, Yogyakarta: Graha Ilmu, 2006

Pressman, R. S. Rekayasa Perangkat Lunak Pendekatan Praktisi 1st Ed, Yogyakarta: ANDI, 2015

Goetsch, D. L and Davis, B. S. Quality Management: Introduction to Total Quality Management for Production, Processing, and Services, New Jersey: Prentice-Hall, 2002

\section{AUTHORS}

First Author - Fahmi Riskian, Master (Cand.) of Business Management, Mercu Buana University, fahmiriskiann@gmail.com 